
МЕДІАСЕРЕДОВИЩЕ ЯК ЧИННИК РЕАЛІЗАЦІЇ ТВОРЧОГО ПОТЕНЦІАЛУ
МАЙБУТНЬОГО ВИХОВАТЕЛЯ ДОШКІЛЬНОЇ ОСВІТИ

\title{
MEDIA ENVIRONMENTS AS A FACTOR FOR REALIZING THE CREATIVE POTENTIAL OF FUTURE PRESCHOOL EDUCATORS
}

УДК [378.091.12:373.2]:316.774 DOI https://doi.org/10.32843/2663$6085 / 2021 / 31-2.32$

\section{Ляпунова В.А.,}

докт. пед. наук,

професесор кафедри дошкільної освіти

і соціальної роботи

Мелітопольського державного

педагогічного університету

імені Богдана Хмельницького

\section{Добровольська л.п.,}

канд. пед. наук,

доцент каседри дошкільної освіти

і соціальної роботи

Мелітопольського державного

педагогічного університету

імені Богдана Хмельницького

Городнича С.В.,

аспірант кафедри дошкільної освіти і соціальної роботи

Мелітопольського державного

педагогічного університету

імені Богдана Хмельницького
Стаття присвячена висвітленню питань щодо медіасередовища як чинника реалізації творчого потенціалу майбутнього вихователя дітей дошкільного віку, необхідності інсоорматизаиіі освітнього простору сучасного закладу дошкільної освіти. Зазначено, що реалізація принципів демократизації і гуманізації педагогічного впливу на дітей згідно Закону України «Про дошкільну освіту» та «Базового компонента дошкільної освіти» вимагає якісної підготовки педагога-дошкільника. Виокремлено важливі функції медіасередовища.

Популяризуються медіа-технології в освітньо-виховному процесі закладу дошкільної освіти з метою актуалізації їх використання при підготовці сучасного вихователя. Автори уточнюють значення понять «медіасередовище», «середовище», «медіа», «творчий процес», «творчий потенціал», розроблених у вітчизняних і закордонних дослідженнях.

у статті розглядаються особливості впливу медіасередовища на творчий процес, творчий потенціал майбутнього вихователя дошкілля. На основі аналізу науковотеоретичних і методичних доробок вчених (Г. Альтшуллера, Д. Мазоха, Л. Петришин, О. Петрунько, А. Яченко), які наголошують, що творчий потенціал є якістю, яка характеризує міру можливостей особистості здійснювати творчу діяльність, охарактеризовано сучасну теорію розв'язання винахідницьких завдань, адаптованих до роботи з дітьми дошкільного віку у творчій діяльності вихователя.

Особливу увагу авторки приділяють позиції сучасної гуманістичної тенденції, що чим більша потреба суспільства у творчій ініціативі особистості, тим гостріше постає необхідність у практичній розробці шляхів реалізації творчого потенціалу вихователядошкільника.

Акцентується увага на тому, що творчий потенціал педагога характеризується властивостями, які називають якостями творчої особистості. у статті доведено, що медіасередовище пов'язує вихователя із дитиною, виконує роль особи, яка навчає, розважає, несе інфрормаційну, комунікаційну, виховну функції, а також пропагуе цінності, розкриває творчий потенціал людини, чинить психологічну дію (однак не завжди позитивну) на поведінку вихованця. Авторки систематизували існуючі доробки вчених, але в майбутньому плану- ють розширити творчу діяльність у цих напрямах.

Ключові слова: медіасередовище, медіа середовище, творчий прочес, творчий потенціал.

The article deals with the issues related to the media environment as a factor in the realization the creative potential of the future educator of preschool children. It also considers the need to inform the educational space of a modern preschool institution. It is noted that the implementation of the principles of democratization and humanization of pedagogical influence on children according to the Law of Ukraine "On Preschool Education" and "Basic Component of Preschool Education" requires quality training of preschool teachers. The author highlighted the important functions of the media environment. Media technologies are popularized in the educational process of preschool education institutions in order to actualize their use in the training of modern educators. The authors specify the concepts of "media environment", "environment", "media", "creative process", "creative potential", developed by native and foreign researches.

The peculiarities of the influence of the media environment on the creative process, the creative potential of the future preschool educator are also considered. Based on the analysis of scientifictheoretical and methodological achievements of scientists (G. Altshuller, D. Mazoha, L. Petryshyn, O. Petrunko, A. Yatsenko), who emphasize that creative potential is a quality that characterizes the extent of a person's ability to carry out creative activities, the modern theory of development is characterized connection of inventive tasks, which are adapted to work with preschool children in the creative activity of the educator.

Emphasis is placed on the fact that the creative potential of a teacher is characterized by properties that are called the qualities of a creative personality.

The article proves that the media environment connects the educator with the child, acts as a person who teaches, entertains, carries information, communication, educational functions, as well as promotes values, reveals the creative potential of man, has a psychological effect (not always positive) on behavior pet. Therefore, the authors have systematized the existing works of scientists, but in the future plan to expand creative activities in these areas.

Key words: media environment, media space, creative potential, media component educator, information space.
Постановка проблеми в загальному вигляді. Сьогодення потребує від науковців у галузі психології та педагогіки виокремлення пріоритетів щодо гармонійного виховання підростаючого покоління. Вчені працюють над створенням такої моделі вихованості людини, яка дала б їй можливість успішно вирішувати складні питання своєї життєтворчості, осягти індивідуальні і суспільні цілі. Особлива увага має бути звернена на розроблення нових освітньо-виховних технологій, які забезпечували б формування й розвиток насамперед духовних здібностей як домінантних і вирішальних для розвитку сучасної людини [2, с. 3].

Реалізація принципів демократизації і гуманізації педагогічного впливу на дітей згідно директивних документів дошкільної освіти вимагає якісно нової підготовки педагога-дошкільника [1; 8]. 
У період модернізації суспільство все більше часу знаходиться в інформаційному полі. У системі освіти країни відбувається інформатизація освітнього простору. Нині ми не уявляємо розвивально-виховного простору без засобів масової інформації та комунікаційних технологій. Медіатехнології стали невід'ємним складником освітньо-виховного процесу вищої освіти.

У доробках вчених важливість фрормування компетентних підходів майбутніх вихователів дошкільної освіти до організації роботи з дітьми в умовах медіасередовища висвітлена не досить. Дослідження медіасередовища як об'єкта у вітчизняній науці представлене невеликою кількістю наукових праць.

Аналіз останніх досліджень і публікацій. Аналіз актуальних досліджень із проблеми використання медіасередовища як чинника реалізації творчого потенціалу майбутніх вихователів дошкільної освіти показав, що останніми десятиліттями у системі вищих навчальних закладів сформувалася принципово нова ситуація, зумовлена інформатизацією освітньо-виховного простору.

Поняття «медіасередовище» досліджували вчені Т. Запорожець, А. Жукова, О. Кепканова, О. Петрунько, С. Шелонаєва, О. Юдіна [3; 7]. О. Петрунько зазначає, що цей термін $є$ особливо вживаним у медіапсихології, у якій ним позначається інформаційне середовище, в якому домінує аудіовізуальна інорормація, створена за допомогою електронних мас-медіа.

Нині цей термін вийшов за межі медіапсихології і вживається значно ширше. У найбільш широкому розумінні він означає середовище, в якому медіа $€$ повноправним учасником соціальної взаємодії і здебільшого «керованим медіа». Медіасередовище $€$ специфічним, енергетично насиченим, «живим» соціальним середовищем, яке утворилося в результаті взаємодії (взаємного накладання, взаємоузгодження, конфліктного зіткнення, взаємної інтерпретації).

У своїх працях О. Петрунько розкриває зміст поняття «медіапростір» і «середовище» («інорормаційне середовище», «медіасередовище») та стверджує, що вони є синонімічними й містять фрактори впливу, тобто те, 3 чого складається середовище (якщо йдеться про інформаційне середовище, то це інформація, тексти).

Поняття «медіасередовище» має два корені «медіа» і «середовище». Це означає, що воно має усі середовищні ознаки, зокрема, неодмінну конотацію впливу на тих, хто в ньому перебуває, і специфічні ознаки, характерні саме для медіасередовища. Корінь «медіа» передбачає, що:

1) життєдіяльність людей і дітей відбувається не лише в реальному, а й у віртуальному світі;

2) люди живуть в умовах обігу величезних масивів інформації, в якій афективний елемент істотно переважає над когнітивним;
3) медіасередовище характеризується масованим впливом на великі аудиторії.

Корінь «середовище» означає, що медіасередовище має всі належні для соціального середовища ознаки - як традиційні соціально-психологічні, так і специфічні, характерні саме для нього [7, с. 168-171].

Отже, більшість учених підкреслює, що медійні методи в освітньо-виховному процесі вищих закладів освіти відіграють значну роль у розкритті творчих здібностей майбутніх студентів в напрямі дошкільної освіти.

Мета статті. Метою статті $€$ висвітлити окремі аспекти понять «медіасередовище», «творчий потенціал», «творчий процес» як невід'ємних фракторів впливу на особистість, реалізацію творчого потенціалу майбутніх вихователів дошкільної освіти; розкрити деякі шляхи підготовки майбутніх вихователів до формування медіакомпетентності дітей дошкільного віку, поєднуючи медійні методи з методами і прийомами теорії розв'язання винахідницьких завдань.

Виклад основного матеріалу. На сучасному етапі підготовки фахівців одним із головних завдань $€$ формування медіакомпетентної особистості. Перші дослідження, присвячені розробці комплексних концепцій медіасередовища і медіакультури, належить Н. Кириловій.

У сучасних фрілософських словниках знаходимо, що термін «середовище» розкривається через категорії «простір», «оточення», «умови», воно $є$ багатофункціональним. На думку Л. Карпова, насамперед середовище є простором. «Середовище - спонтанний і організований вплив, якого зазнає індивід на різних етапах фрункціонування й розвитку», - наголошує І. Бех [2, с. 658].

Створення особистісно-розвивального середовища $€$ головним напрямом пошуку нових виховних технологій, які ґрунтуються на використанні певних механізмів побудови такого середовища. Одним із таких механізмів є функціональне включення педагогів у спільну діяльність. Колектив педагогів виступає не в декларативній фрормі «групи колег-однодумців», а у формі «колективу творців», який діє відповідно до організованого порядку, ритуалів, прийнятих у певному середовищі. Педагоги залучаються до спільної дитячої діяльності як її рівноправні творчі учасники [2, с. 620-621].

Сучасні інноваційні медійні методи спонукають до підготовки педагогічної діяльності вихователядошкільника. На сучасному етапі зростає потреба суспільства у вихователях, здатних творчо підходити до будь-яких змін, нетрадиційно і якісно вирішувати існуючі проблеми, що зумовлено прискоренням темпів розвитку суспільства і необхідністю підготовки особистості до життя в умовах, які швидко змінюються. Принцип діяльності полягає 
у тому, що особистість не отримує знання в готовому вигляді, а здобуває їх у процесі навчальної діяльності. При цьому передбачено максимальну пізнавальну активність дитини, а фрункція вихователя, вчителя полягає в організації їх навчальної діяльності.

Важливими умовами практичної реалізації принципу діяльності за І. Бехом є:

1) принцип мінімаксу - навчальні заклади зобов'язані запропонувати вихованцю, учневі зміст освіти на максимальному (творчому) рівні й забезпечити його засвоєння на рівні соціально безпечного мінімуму (освітнього стандарту);

2) принцип творчості - максимальна орієнтація на творче начало у навчальній діяльності [2, с. 631-632].

Вихователю необхідно враховувати, що за надмірної регламентації поведінки, коли дитина вже має відповідні можливості для самостійної регуляції поведінки, але ії дії обмежуються, пригнічується творча активність: вона стає безініціативною, чекає вказівок ззовні і звикає орієнтуватися лише на них [2, с. 86].

На думку І. Беха, сучасний навчально-виховний процес здебільшого орієнтований на розумовий розвиток особистості, виховання волі в ньому недооцінюється. Момент діяльності $€$ визначальним у волі. Вольова діяльність не нав'язується суб'єктові: він діє не через примус, а вільно прийнявши рішення. Така діяльність є самодіяльністю суб'єкта. Згодом воля здебільшого стає діяльністю творчою, що вище вона піднімається у своєму розвитку, то чіткішим стає її творчий характер [2, c. 489-490].

А. Маслоу першим вказав, що творчість $€$ найбільш універсальною характеристикою людей, яких він вивчав або спостерігав. Він розглядав творчість як рису, потенційно присутню у всіх людях від народження. Однак вчений визнавав, що більшість людей втрачають цю якість у результаті «окультурення», чому сприяє офріційна освіта.

На думку А. Маслоу, оскільки здатність до творчості закладена у кожному з нас, то вона не вимагає спеціальних талантів або здібностей. Творчість - універсальна фрункція людини, яка веде до усіх форм самовираження [9, с. 486]. Чим більше і повніше особистість використовує можливості середовища, тим більш успішно відбувається ії вільний та активний саморозвиток: вона одночасно є продуктом і творцем свого середовища, яке йому дає фрізичну основу для життя й робить успішним інтелектуальний, моральний, суспільний, духовний і творчий розвиток [6, с. 277].

Одна із перших спроб розкрити структуру творчого процесу належить П.К. Енгельмейєру, який визначив його ступені. Першою дією $є$ зародження задуму - акт, у якому виявляється інтуїтивне мислення. Другий етап - дискурсивне мислення: логіка, міркування та емпіричне дослідження. На третьому етапі винахідник починає взаємодіяти із матеріальними явищами світу. Будь-який винахід постає у тричленній структурі: принцип, схема (система, план) і конструкція. П.К. Енгельмейєр пропонує такі ознаки людської творчості: штучність, доцільність, раптовість, цілісність. Творчий продукт має ідею, а всі частини твору об'єднуються у певну цілісність [5, с. 277-278].

У процесі вивчення зазначених вище освітніх компонентів у здобувачів вищої освіти розвивається система як особистісних якостей (творча активність, конструктивне мислення, мовленнєва активність, етична поведінка, загальні та спеціальні компетенції), так і компетентностей вихователя, які в позитивно створених умовах потребують розкриття творчого потенціалу.

Творчий потенціал будь-якої людини, в тому числі й педагога, характеризується властивостями, які називають знаками творчої особистості. Вчені-педагоги наводять різні ознаки. Так, вони виділяють здатність особистості помічати й формулювати альтернативи, піддавати сумніву явне, уникати поверхових фрормулювань, побачити перспективу, вміння побачити знайомий об'єкт у новому контексті [4, с. 121].

Нове педагогічне мислення, яке яскраво виявляється в інноваційній навчально-виховній діяльності, не $є$ психологічно безболісним процесом для педагогічного співтовариства. У ньому спостерігається дія антиінноваційних бар'єрів, що гальмують нову педагогічну орієнтацію, а подолання яких є професійно важливим завданням [2, с. 278].

Варто нагадати, що родоначальником теорії розв'язання винахідливих завдань (далі - ТРВ3) $€$ учений-дослідник Г. Альтшуллер, який заснував її у 1946 році. Вищою метою теорії $€$ сприяння розвитку творчих якостей людини. Спочатку ТРВ3 створювалася як технічна дисципліна, але згодом вона почала застосовуватися у психології, педагогіці для формування творчої особистості. У всесвітній комп'ютерній мережі Інтернет стрімко збільшується обсяг інформаційних матеріалів про ТРВ3. На жаль, в Україні школи «ТРВЗ-педагогіки» розвиваються украй слабко [10, с. 5-10].

Розвивати творчі якості означає переборювати замкнутість, боязкість, учитися відстоювати свою точку зору, а, потрапляючи у складні ситуації, знаходити власні оригінальні рішення. Ми часто чуємо від педагогів фрразу: «У своїй роботі ми використовуємо елементи ТРВЗ», але окремі елементи теорії в роботі не дають бажаних результатів. Педагогам необхідно більше заглиблюватися у теорію, щоб бачити розвиток ігор, рух логіки. А. Яценко стверджує, що добре самим усвідомити переваги ТРВ3.

Практика $є$ ресурсом, цінним компонентом у пізнанні, перевірці й поповненні знань здобувача 
вищої освіти про особистість дитини, яка потребує допомоги вихователя, що є передумовою збудження інтересу до творчої педагогічної діяльності $[4$, c. 71$]$.

Під час проходження педагогічної практики в дошкільних навчальних закладах комбінованого типу № 2 «Казка» та № 36 «Берізка» Мелітопольської міської ради Запорізької області здобувачі вищої освіти Мелітопольського державного педагогічного університету імені Богдана Хмельницького активно поєднують в освітньо-виховному процесі медійні методи 3 методами й інструментальними прийомами ТРВЗ, адаптованими до роботи з дітьми старшого дошкільного віку. Цінним матеріалом для оволодіння методикою ТРВЗ для нас $€$ посібник А. Яценко «Джерельце творчості» (2011 рік).

Вихователі почали активно опановувати прийоми роботи 3 дитиною, засновані на ії природному прагненні до пізнання світу, що дозволяє формувати у дітей творчу уяву, основи діалектичного мислення [10, с. 7].

Висновки. Серед учених немає єдності щодо визначення поняття «медіасередовище». Якщо у закладі вищої освіти та закладі дошкільної освіти створити сприятливі умови для впровадження інноваційних медійних методів в освітньо-виховний процес, то з упевненістю можна стверджувати, що значно зростуть показники успішності студентів і розкриється їхній творчий потенціал. Це забезпечить розвиток медійної грамотності як вихователя, так і дитини, розвиток аналітичних конструктивно-проектувальних, організаторських умінь, творчих здібностей майбутніх педагогів.
Перспективою подальших досліджень є дослідження впливу сучасного медіапростору на якість психолого-педагогічних компетентностей майбутніх вихователів дошкільної освіти.

\section{БІБЛІОГРАФІЧНИЙ СПИСОК:}

1. Базова програма розвитку дитини дошкільного віку «Я у Світі» / М-во освіти і науки України, АПН України; наук. ред. та упоряд. О.Л. Кононко. Київ : Світич, 2008. 430 с

2. Бех І.Д. Виховання особистості. Київ : Либідь, 2008. $848 \mathrm{c}$

3. Запорожець Т.М. Медійний простір як середовище зародження інсролюдини. URL: http://ippo.org.ua/ index.php?op.

4. Мазоха Д.С. На шляху до педагогічної профресії (Вступ до спеціальності) : навчальний посібник. Київ : Центр навчальної літератури, 2005. 168 с.

5. Основи психології / за загальною редакцією Киричука О.В., Романець В.А. 3-тє вид., стереотип. Київ : Либідь, 1997. 632 с.

6. Петришин Л.Й. Формування креативності майбутніх соціальних педагогів: теоретико-методичний аспект : монограсрія / Людмила Йосипівна Петришин. Тернопіль : Астон. 2014, 400 с.

7. Петрунько О.В. Діти і медіа: соціалізація в агресивному медіасередовищі : монографрія. Полтава : ТОВ НВП «Укрпромторгсервіс», 2010, 480 с.

8. Поніманська Т.І., Дичківська І.М. Дошкільна педагогіка. Практикум. Навчальний посібник для студентів вищих навчальних закладів, спеціальність «Дошкільне виховання». Київ : Видавничий Дім «Слово», 2004. 353 с.

9. Хьелл Л., Зиглер Д. Теория личности (Основные положения и применение). СПб : Питер Ком, 1998, $608 \mathrm{c}$.

10. Яценко А.В. Джерельце творчості. ТРВЗ. Харків : Ранок, 2011. 176 с. 